\title{
Prevalence and causes of blindness in an urban area of Paraguay
}

\author{
Prevalência e causas de cegueira em uma população urbana do Paraguai
}

Fernando Yaacov-Peña ${ }^{1}$, David Jure ${ }^{1}$, José Ocampos ${ }^{1}$, Margarita Samudio $^{2}$, João Marcello Furtado ${ }^{3}$, Marissa Carter $^{4}$, Van Charles Lansingh $^{5}$

\begin{abstract}
Purpose: To determine the prevalence and causes of blindness in Piribebuy, Paraguay Methods: A population based study was conducted from September to November 2007 in Piribebuy, Paraguay. Based on the city map, seven clusters were randomly selected, containing 22 to 36 squares ( 423 to 578 houses) each, where all subjects $\geq 40$ years old who agreed to participate were included in the study. Presenting vision acuity (VA) was obtained for each eye, with'E'Snellen charts 6 meters far from the patient with appropriate light. Eyes with VA $\leq 20 / 60$ were also tested with the pinhole. Objective and subjective refraction was performed, followed by examination of anterior segment under the slit-lamp, Goldmann applanation tonometry, and pupil dilatation with $0.5 \%$ tropicamide plus $0.5 \%$ phenylephrine, followed by evaluation of the posterior pole. Best corrected visual acuity was used to classify the patients as follows: blindness was defined as visual acuity of the better eye $<20 / 400$ low vision as $20 / 400 \leq V A<20 / 60$ and visual impairment as $V A \leq 20 / 60$. Similar to the methodology followed by the Rapid Assessment of Avoidable Blindness studies, in patients presenting more than one eye disease equally contributing to visual loss, only the most treatable or avoidable cause was recorded.

Results: 402 subjects received ophthalmological evaluation (92.2\% of the original sample). Prevalence of blindness and low vision adjusted for gender and age was $1.0 \%(95 \% \mathrm{Cl}: 0.3-2.7)$ and $4.5 \%(95 \% \mathrm{Cl}: 2.8-7.1)$, respectively. Cataract was the only cause of blindness and the main cause of low vision ( $77.8 \%$ of the cases), followed by age-related macular degeneration (11.1\%), pterygium (5.6\%) and bilateral macular scar (5.6\%).
\end{abstract}

Conclusion: The prevalence of blindness in Piribebuy was $1 \%$ and the main cause was cataract.

Keywords: Cataract/complications; Blindness/epidemiology; Blindness/etiology; Visual acuity; Epidemiologic studies; Paraguay

\section{RESUMO}

Objetivo: Determinar a prevalência e causas de cegueira em Piribebuy, Paraguay. Métodos: Um estudo populational foiconduzido de setembro a novembro de $2007 \mathrm{em}$ Piribebuy, Paraguay. Baseado no mapa da cidade, sete agrupamentos foramaleatoriamente selecionados, contendo 22 a 36 quarteirões ( 423 a 578 casas) cada, onde todos os indivíduos $\geq 40$ anos de idade, que concordaram em participar, foram incluídos no estudo. A acuidade visual (AV) conforme apresentada foi obtida para cada olho, com Tabela de Snellen a 6 metros do paciente, com luz apropriada. Olhos com AV $\leq 20 / 60$ também foram testados com orifício estenopeico. Refrações objetiva e subjetiva foram realizadas, seguido de avaliação da câmara anterior sob lâmpada de fenda, tonometria de aplanação de Goldmann e dilatação pupilar com tropicamida a 0.5\% e fenilefrina a $0.5 \%$, seguido de avaliação do polo posterior. A melhor acuidade visual corrigida foi usada para classificar os pacientes nos sequintes grupos: cequeira foi definida como acuidade visual do melhor ol ho $<20 / 400$, baixa visão como 20/400 $\leq A V<20 / 60$ e incapacidade visual como AV<20/60. Similar aos estudos de "Rapid Assessment of Avoidable Blindness", em pacientes que apresentaram mais de uma doença ocular igualmente contribuindo com perda visual, apenas a causa mais facilmente tratável ou prevenivel foi considerada.

Resultados: 402 indivíduos foram submetidos à avaliação oftalmológica (92\% da amostra original). A prevalência de cegueira e baixa visão ajustada para sexo eidade foi 1,0\% (95\% IC: 0,3-2,7) e 4,5\% (95\% IC: 2,8-7, 1), respectivamente. Catarata foi a única causa de cegueira e a maior causa de baixa visão (77.8\% dos casos), seguido por degeneração macular relacionada à idade (11,1\%), pterígio (5,6\%) e cicatriz macular bilateral $(5,6 \%)$. Conclusão:A prevalência de cegueiraem Piribebuy foide 1\% eaprincipal causaécatarata.

Descritores: Catarata/complicações; Cegueira/epidemiologia; Cegueira/etiologia; Acuidade visual; Estudos epidemiológicos; Paraguai

\section{INTRODUCTION}

There are 39.36 million people presenting bilateral blindness worldwide, 3.2 of them living in the Americas ${ }^{(1)}$. In 1999, VISION 2020, a global initiative created by the World Health Organization (WHO) and the International Agency for the Prevention of Blindness (IAPB) was launched with the aim to eliminate avoidable blindness by the year $2020^{(2,3)}$. The program only reached Latin America in 2004, as a partnership between IAPB, the Pan American Association of Ophthalmology (PAAO), and the Pan American Health Organization $(\mathrm{PAHO})^{(4)}$, and since then progress has been made in the fight to reduce the impact of avoidable blindness in the region. From 2005 to 2008, for example, the cataract surgical rate (CSR - defined as the number of cataract surgeries performed per million individuals per year) has improved in almost all Latin American countries ${ }^{(5)}$.
There is a limited number of articles describing epidemiological aspects of eye diseases in Paraguay ${ }^{(4)}$. The only available data about the prevalence of blindness in the country was published in 2003, when Duerksen et al., examined a randomized sample composed of more than 2,000 subjects $\geq 50$ years old nationwide ${ }^{(6)}$. In that study, $3.17 \%$ of the subjects were bilaterally blind (presenting $V A<20 / 400$, adjusted for age and gender; $95 \% \mathrm{Cl}: 2.2-4.4$ ), and the main cause was cataract ( $64 \%$ of the total).

It is important to generate more data about community eye health in the country to assess the priority eye diseases, and also to evaluate if progress has been made since last evaluation. Thus, a better description of the prevalence and causes of blindness would give the eye care providers more tools to advocate for funding to support further prevention of blindness programs.

Submitted for publication: March 8, 2012

Accepted for publication: August 17, 2012

Study carried out at Fundación Visión, Asunción, Paraguay and Instituto de Investigaciones em Ciencias de la Salud, Universidad Nacional de Asunción, Paraguay.

${ }^{1}$ Fundación Visión, Asunción, Paraguay.

2 Instituto de Investigaciones en Ciencias de la Salud - Universidad Nacional de Asunción, Paraguay.

Casey Eye Institute, Oregon Health and Science University, Portland, Oregon, USA.

${ }^{4}$ Strategic Solutions, Cody, Wyoming, USA.

${ }_{5}^{5}$ International Agency for the Prevention of Blindness - IAPB/V2020 LatinAmerica, Weston, Florida,

USA.

Funding: No specific financial support was available for this study.

Disclosure of potential conflicts of interest: F.Yaacov-Peña, None; D.Jure, None; J.Ocampos, None; M.Samudio, None; J.M.Furtado, None; M.J.Carter, None; V.C.Lansingh, None.

Correspondence address: Fernando Yaacov-Peña. Calle 120 No. 7-38, Bogota, Colombia E-mail: ojosalud@yahoo.com

Registration in the Fundación Visión Research Ethics Committee: 003/2007 
The aim of the present study is to determine the prevalence and causes of blindness and low vision in Piribebuy, Paraguay, and compare the findings with available data in the literature.

\section{METHODS}

The Piribebuy Eye Study is a population-based study performed in Piribebuy, Paraguay, from September to November 2007, to determine the prevalence and causes of blindness in the area. Piribebuy is a small town located $72 \mathrm{~km}$ east from Asunción. Data from the last national census described a total of 22,807 inhabitants, 2,626 of them being 40 years old or above. Demographic and socioeconomic characteristics from Piribebuy are representative from the entire Cordillera Department. Also, the distribution of the age groups is similar to the rest of the country ${ }^{(7,8)}$.

To calculate the sample size, based on a previous publication ${ }^{(6)}$ we estimated a prevalence of blindness ranging from 2 to $3.2 \%$ in individuals aged 40 or older, which results in a sample of 436 subjects $(95 \% \mathrm{Cl})$ through the use of the Epi Info 2000 software.

Based on the Piribebuy city map, seven clusters were randomly selected, containing 22 to 36 squares (423 to 578 houses) each (Table 1).

All individuals aged $40+$ years old living in these squares were notified prior to eye exam. The aim of the study and the examination procedure were explained to the subjects, and those who gave verbal consent were examined.

Eye examination was performed by three third-year residents in ophthalmology from Fundación Visión, under the supervision of an experienced ophthalmologist. In a local ophthalmological clinic, presented vision acuity (VA) was obtained for each eye, with ' $E$ ' Snellen charts 6 meters far from the patient with appropriate light. Objective and subjective refraction was performed and also best corrected visual acuity (BCVA) was obtained, followed by examination of anterior segment under the slit-lamp, Goldmann applanation tonometry, pupil dilatation with $0.5 \%$ tropicamide plus $0.5 \%$ phenylephrine and evaluation of the posterior pole with a 90D lens and with indirect ophthalmoscope and 20D lens. Patients who could not attend the ophthalmological appointment were submitted to visual acuity (VA) measurement, refraction, eye examination with a portable slit-lamp and indirect ophthalmoscope with a 20D lens in their houses. Best corrected VA was used to classify the patients as follows: blindness was defined as VA of the better eye $<20 / 400$, low vision as $20 / 400<\mathrm{VA}<20 / 60$ and visual impairment as $\mathrm{VA}<20 / 60^{(9)}$.

According to the recommendation from the World Health Organization and the methodology followed by the Rapid Assessment of Avoidable Blindness (RAAB) studies in patients presenting more than one eye disease similarly contributing to visual loss, only the most treatable or avoidable cause was taken into consideration for analysis ${ }^{(10)}$.

Table 1. Number of squares and houses selected per neighbourhood for the Piribebuy Eye Study

\begin{tabular}{lcc}
\hline Neighbourhood & Squares & Houses \\
\hline Santa Ana & 30 & 423 \\
Centro & 23 & 278 \\
Maria Auxiliadora & 26 & 376 \\
San Blas 1 & 24 & 506 \\
San Blas 2 & 22 & 578 \\
Virgen Rosario 1 & 36 & 535 \\
Virgen Rosario 2 & 29 & 445 \\
\hline Total & $\mathbf{1 9 0}$ & $\mathbf{3 1 4 1}$ \\
\hline
\end{tabular}

\section{RESULTS}

Of the 436 individuals selected, 402 were examined $(92.2 \%$ of the original sample), and $60.4 \%$ of them were women (Table 2). Subjects ranged from 40 to 97 years old (mean $56.9 \pm 12.3$ years old).

The prevalence of blindness found was 1.00\% (95\% Cl $0.3-2.7 \%)$, all of them caused by cataract (Table 3). Eighteen subjects presented low vision ( $4.5 \%$ of the sample), most of them presenting cataract as the primary diagnosis (77.8\% of the total cases of low vision), followed by age-related macular degeneration (AMD) (11.1\%), pterygium (5.6\%) and macular scar (5.6\%). As expected, the prevalence of visual impairment was higher in older individuals (Figure 1). Only one patient under 50 years old presented low vision and no patient presented blindness (Table 4).

\section{DISCUSSION}

To the authors' knowledge, this is the second population-based study performed in Paraguay to estimate the prevalence of blindness and visual impairment. In this Paraguayan population, cataract was the only cause of blindness and the most frequent cause of visual impairment, according the methodology followed by the RAAB studies.

We found a lower prevalence of visual impairment in individuals $\geq 50$ years old than the previous study performed with by Duerksen et al., (7.9\%; 95\% Cl 4.9-11.8\% versus $13.88 \% ; 95 \% \mathrm{Cl} 11.9-16.1 \%)^{(6)}$. This fact could be explained by different methodologies (urban area versus nationwide, inclusion of refractive errors as a cause of blindness or not), but also by an increment in programs to prevent blindness in the country. Since 2003, for example, the CSR in Paraguay raised from $650^{(6)}$ to $1000,{ }^{(5)}$ although this number is still insufficient to cover the population needs ${ }^{(11)}$.

In contrast with other population-based studies performed in Latin America, ${ }^{(4)}$ glaucoma and diabetic retinopathy were not among the main causes of blindness in the present study. One possible explanation is the fact that cataract was very prevalent among visually impaired subjects in the sample, and this disease is considered more preventable and treated. Moreover, concomitant diseases were not

Table 2. Prevalence of blindness in men and women, low vision and visual impairment adjusted for age and gender $(n=402)$

\begin{tabular}{|c|c|c|c|c|c|c|c|}
\hline \multirow[b]{2}{*}{ Presenting VA } & \multicolumn{2}{|c|}{$\begin{array}{c}\text { Men } \\
(n=157)\end{array}$} & \multicolumn{2}{|c|}{$\begin{array}{l}\text { Women } \\
(n=245)\end{array}$} & \multicolumn{2}{|c|}{$\begin{array}{c}\text { Total } \\
(n=402)\end{array}$} & \multirow[b]{2}{*}{$(95 \% \mathrm{Cl})$} \\
\hline & $\mathbf{n}$ & $\%$ & $\mathbf{n}$ & $\%$ & $\mathbf{n}$ & $\%$ & \\
\hline $\begin{array}{l}\text { Blindness } \\
(V A<20 / 400)\end{array}$ & 1 & 0.6 & 3 & 1.2 & 4 & 1.0 & $0.3-2.7 \%$ \\
\hline $\begin{array}{l}\text { Low vision } \\
(20 / 400<\mathrm{VA}<20 / 60)\end{array}$ & 6 & 3.8 & 12 & 4.9 & 18 & 4.5 & $2.8-7.1 \%$ \\
\hline $\begin{array}{l}\text { Visual impairment } \\
(V A<20 / 60)\end{array}$ & 7 & 4.5 & 15 & 6.1 & 22 & 5.5 & $3.5-8.3 \%$ \\
\hline
\end{tabular}

$\mathrm{VA}=$ visual acuity; $\mathrm{Cl}=$ confidence interval.

Table 3. Causes of low vision, blindness and visual impairment in Piribebuy $(n=402)$

\begin{tabular}{lccccc}
\hline Presenting VA & Cataract (\%) & AMD (\%) & Pterygium (\%) & MS (\%) & Total \\
\hline $\begin{array}{l}\text { Blindness } \\
(\mathrm{VA}<20 / 400)\end{array}$ & $4(1.0)$ & - & - & - & 4 \\
$\begin{array}{l}\text { Low vision } \\
(20 / 400<\mathrm{VA}<20 / 60)\end{array}$ & $14(77.8)$ & $2(11.1)$ & $1(5.6)$ & $1(5.6)$ & 18 \\
$\begin{array}{l}\text { Visual impairment } \\
(\mathrm{VA}<20 / 60)\end{array}$ & $18(81.8)$ & $2(9.1)$ & $1(4.5)$ & $1(4.5)$ & 22 \\
\hline VA & & & & & \\
\hline
\end{tabular}




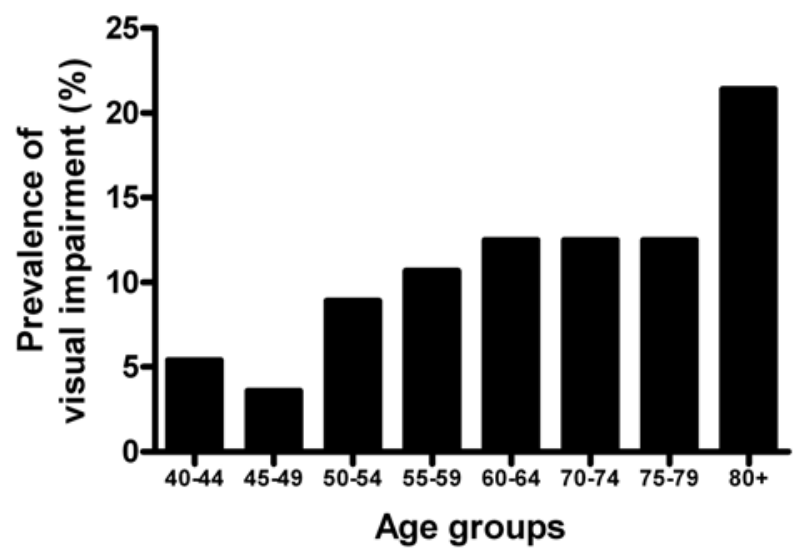

Figure 1. Prevalence of visual impairment among the age groups, Piribebuy Eye Study.

Table 4. Prevalence of blindness, low vision and visual impairment in subjects under 50 years old $(n=135)$ and $\geq 50$ years old $(n=267)$

\begin{tabular}{|c|c|c|c|c|}
\hline Presenting VA & $\begin{array}{c}\text { 40-49 years old } \\
(\mathrm{N}=135) \\
n(\%)\end{array}$ & $95 \% \mathrm{Cl}$ & $\begin{array}{c}\geq 50 \text { years old } \\
(N=267) \\
n(\%)\end{array}$ & $95 \% \mathrm{Cl}$ \\
\hline $\begin{array}{l}\text { Low vision } \\
(20 / 400<V A<20 / 60)\end{array}$ & $1(0.7)$ & $0.0-4.1$ & $17(6.4)$ & 3.8-10.1 \\
\hline $\begin{array}{l}\text { Blindness } \\
(\text { VA }<20 / 400)\end{array}$ & $0(0.0)$ & - & $4(1.5)$ & $0.4-3.8$ \\
\hline $\begin{array}{l}\text { Visual impairment } \\
(V A<20 / 60)\end{array}$ & $1(0.7)$ & $0.0-4.1$ & $21(7.9)$ & $4.9-11.8$ \\
\hline
\end{tabular}

$\mathrm{VA}=$ visual acuity; $\mathrm{Cl}=$ confidence interval.

recorded if they contributed equally to visual loss, and this likely biased the findings toward cataract. Patients having dense cataracts could also have some pathology in the posterior pole such as glaucoma or diabetic retinopathy that could not be assessed. Also, a healthier lifestyle (e.g.: eating habits) could also contribute for these findings.

The ProyectoVer, performed with Hispanics living in Arizona, USA, also found cataract was the main cause of visual impairment (best corrected vision in the better eye worse than 20/40), (12) but the lead cause of blindness (best corrected vision in the better eye $\leq 20 / 200$ ) was glaucoma, while in the present study no blind subjects due to this disease were found.

Surveys using the rapid assessment of avoidable blindness (RAAB) or the rapid assessment of cataract surgical services (RACSS) methodology examines subjects $\geq 50$ years old, ${ }^{(10,13)}$ while the Los Angeles Latino Eye Study $(L A L E S)^{(14)}$ and the Proyecto Ver $^{(12)}$ examined indivi- duals aged 40 or above. In the present study, only one subject (0.7\%) aged $<50$ years old presented visual impairment and none presented blindness. The assessment of only individuals exclusively $50+$ years old would provide a good indicator for the prevalence of blindness, visual impairment and its causes, using a smaller sample size ${ }^{(15)}$. At least for the Paraguayan situation, for further studies we recommend the use of 50 years old as a cut-off.

\section{CONCLUSION}

Despite of the progress of the interventions for the prevention of blindness in Paraguay, avoidable causes of blindness and visual impairment still play an important role in Piribebuy. Improvement in patient's accessibility to high-quality cataract surgical services, affordability and also increasing patient's willingness to undergo surgery could reduce the burden of blindness in this city.

\section{REFERENCES}

1. Pascolini D, Mariotti SP. Global estimates of visual impairment: 2010. Br J Ophthalmol. 2012;96(5):614-8

2. Resnikoff S, Pararajasegaram R. Blindness prevention programmes: past, present, and future. Bull World Health Organ. 2001:79(3):222-6.

3. Resnikoff S, Pascolini D, Etya'ale D, Kocur I, Pararajasegaram R, Pokharel GP, et al. Global data on visual impairment in the year 2002. Bull World Health Organ. 2004;82(11): 844-51.

4. Furtado JM, Lansingh VC, Carter MJ, Milanese MF, Peña BN, Ghersi HA, et al. Causes of blindness and visual impairment in Latin America. Surv Ophthalmol. 2012;57(2): 149-77.

5. Lansingh VC, Resnikoff S, Tingley-Kelley K, Nano ME, Martens M, Silva JC, et al. Cataract surgery rates in latinamerica: a four-year longitudinal study of 19 countries. Ophthalmic Epidemiol. 17(2):75-81.

6. Duerksen R, Limburg H, Carron JE, Foster A. Cataract blindness in Paraguay - results of a national survey. Ophthalmic Epidemiol. 2003;10(5):349-57.

7. Paraguay. Dirección General de Estadística, Encuesta y Censo. Departamento de Cordillera. Proyección de la Población por sexo, según grupos etarios. Assuncion: Gobierno del Paraguay; 2000.

8. Paraguay. Dirección General de Estadística, Encuesta y Censo. Censo del Paraguay. Piribebuy: principales indicadores, según barrio y localidad. Assuncion: Gobierno del Paraguay; 2002.

9. World Health Organization. International Statistical Classification of Diseases and Related Health Problems: ICD-10. 2a ed. Geneva; WHO; 2004. v.1

10. Kuper H, Polack S, Limburg H. Rapid assessment of avoidable blindness. Community Eye Health. 2006;19(60):68-9.

11. Taylor HR. Cataract: how much surgery do we have to do? Br J Ophthalmol. 2000; 84(1):1-2.

12. Rodriguez J, Sanchez R, Munoz B, West SK, Broman A, Snyder RW, et al. Causes of blindness and visual impairment in a population-based sample of U.S. Hispanics. Ophthalmology. 2002;109(4):737-43.

13. Limburg H, Kumar R, Indrayan A, Sundaram KR. Rapid assessment of prevalence of cataract blindness at district level. Int J Epidemiol. 1997;26(5):1049-54

14. Varma R, Ying-Lai M, Klein R, Azen SP; Los Angeles Latino Eye Study Group. Prevalence and risk indicators of visual impairment and blindness in Latinos: the Los Angeles Latino Eye Study. Ophthalmology. 2004;111(6):1132-40.

15. Dineen B, Foster A, Faal H. A proposed rapid methodology to assess the prevalence and causes of blindness and visual impairment. Ophthalmic Epidemiol. 2006; 13(1):31-4 